\title{
The Evolution of Soviet Power's Religious Policy during the Great Patriotic War
}

\author{
Gulzhaukhar Kokebayeva $^{1}$, Yerke Kartabayeva ${ }^{1} \&$ Aigul Sadykova ${ }^{1}$ \\ ${ }^{1}$ Faculty of History, Archeology and Ethnology, Al-Farabi Kazakh National University, Almaty, Kazakhstan \\ Correspondence: Gulzhaukhar Kokebayeva, Faculty of History, Archeology and Ethnology, Al-Farabi Kazakh \\ National University, Al-Farabi ave., 71, Almaty, 050040, Kazakhstan. Tel: 7-727-377-3337; ext.: 1284. E-mail: \\ kokebayeva@mail.ru
}

Received: December 23, 2014 Accepted: March 13, 2015 Online Published: May 16, 2015

doi:10.5539/ass.v11n13p235 URL: http://dx.doi.org/10.5539/ass.v11n13p235

\begin{abstract}
The article is devoted to the study of one of the actual problems of the Soviet power's internal policy: the evolution of the religious policy during the war. According to a wide range analysis of published materials and archival documents the article states that the religious policy of the Soviet power during the Great Patriotic War is characterized by some mitigation, a string of concessions, however there were no deep changes or, as some researchers believe that it lacks of "a liberal turn" in the religious policy of the Soviet power. A certain part of actions of the Soviet power in the sphere of religion had a declarative, nominal and propaganda character.
\end{abstract}

Keywords: religious policy, religion in the USSR, atheist propaganda, antireligious policy, mitigation of antireligious policy, secularization

\section{Introduction}

In 1917 in Russia there was an attempt to create a new Soviet statehood, to build a socialist society and to raise a new "Soviet" type person. It was followed by radical destruction of people's age-old way of life and set of "a scientific worldview". One of the postulates of the Soviet ideological doctrine was the denial of any positive meaning of religion, a church. The Soviet ideologists stated religion was "opium" for people. The Soviet power conducted a fierce fight against religion as an antiscientific theory, church and clergy and religious consciousness. The authorities encouraged the formation of atheistic organizations to advocate antireligious propaganda in order to extrude the religion from all spheres of social activities. During the World War II the antireligious propaganda ceased for a while and it led to the numerous publications about "a radical turn" in the Soviet religious policy in the Post-Soviet historiography. The studying of this issue will help to get deep understanding of the Soviet power's policy during the World War II, to find answers to a number of controversial questions, thereby to restore an objective picture.

The collapse of the USSR allowed to start the studying this issue however some foreign researchers have been successfully working on this topic for a long time. In his monograph W.B. Husband analyzed the Soviet power's activities directed towards the Orthodox church and the history of the Soviet atheism (Husband, 2000). Studying the published Russian archival materials W.B. Husband comes to the conclusion that no warring party - neither the Soviet power nor Orthodox church - reached a clear victory: most of Russian population did not participate in the antireligious campaign as well as did not show resistance to the atheistic promotion. One of the most studied aspects of the Soviet power's policy is its relation to Islam (Ro'i, 2000; Khalid, 2007; Schwartz, 2009). According to A. Khalid, as a result of the Soviet power's antireligious policy the best samples of the Islamic doctrine were destroyed, and Islam kept its positions only in the sphere of customs and traditions; therefore during the Post-Soviet period the returning to Islam was as restoration of the traditions destroyed under communism. Y. Ro' $i$ notes that in the USSR despite the hostility of the Soviet power both officially recognized mosques and clergy and unregistered mosques and mullahs remained. Investigating S.S. Schwartz analyzes the authorities' attitude to various religions and proves how and why Islam survived in the conditions of the Soviet power.

\section{Research Methods}

The authors investigate the evolution of Soviet power's religious policy during the Great Patriotic War based on a wide range analysis of the Kazakhstani archives and Post-Soviet publications. The concept of multidimensionality 
and alternativeness of historical reality was used in studying of this issue. We consider the alternativeness of reality as opportunities which really existed in the past. We look for the reasons for changes and "thaw" in the church policy of the Soviet power in the decision making issue on alternative opportunities of secularization not used earlier.

\section{Results and Discussion}

The decree of the Council of People's Commissars of the RSFSR "About a Freedom of Worship, Church and Religious Societies" of February 28, 1918 declared the separation of church and state emphasized a secular character of the Soviet state. It was prohibited to practice religious ceremonies during state or public legal activities. There was an inscription about religious affiliation of citizens in official documents. At the same time the decree provided citizens with the right to practice any religion if they wish. All churches and religious societies were subject to the general provisions on private societies and unions. These basic provisions of the decree were included in the first Soviet Constitution. It was emphasized that in order to provide people with a valid freedom of worship, church was separated from state, school was separated from church, and all citizens are free to advocate religious and antireligious propaganda. Upon the end of the Civil War the authorities took new measures against church. In February, 1922 the state confiscated jewelry from church to struggle against famine. The priests and believers' resistance caused disorders which were followed by trials and executions.

The fight against religion together with the campaign for the abolition of churches which began after Bolsheviks' coming to the power proceeded actively in the $30 \mathrm{~s}$ and later. The process of secularization in the twenties generally took place intensively in the cities, and in the thirties rural areas were involved in it as well (Steindorff, 2001). From 1917 to 1933 only in one region of Almaty area of Kazakhstan the number of churches was 6 times reduced (Timofeeva, 2007, p. 17). In the twenties the Soviet government mainly fought against church, tried to undermine its material resources and there was closing of churches and monasteries everywhere, in the 30 s the government tried to eradicate religion at all, to introduce a materialistic view instead of religion, started "bringing up" a generation of atheists. The policy of the Soviet government in the sphere of religion was based on the ideas of scientific socialism, i.e. the idea of socialism was considered a scientific theory, and religion was thought antiscientific.

The members of the Communist Party were forbidden to perform religious rites, otherwise they were subject to the exception from the party on the basis of the resolution of the Central Committee of the RCP (of Bolsheviks) of July 21, 1921 "About Examination of Party Members, about their Revision and Purge". Following the results of the purge 4855 people were expelled from party bodies or translated in candidates, which made 22 percent of the number of one party organization (Kommunisticheskaia, 1987, p. 391).

1939 turned out to be a turning point in the religious policy of the Soviet power. After the entry of the Soviet troops in the territory of Poland and the accession of Western Ukraine and Western Belarus to the USSR, the Soviet government faced the fact of the inclusion in the state life of the country of the areas where church and religion had not been an object of repressions and persecutions. The structure of the population of the USSR in the fall of 1939 and in the summer of 1940 with the accession of the countries of the Baltic, Bessarabia and Northern Bukovina included over 7500 thousand Orthodox believers organized into dioceses and parishes (Shkarovskiy, 2010, p. 133).

On November 28, 1943 the Council of People's Commissars adopted the resolution "About an Order of Opening Churches" according to which petitions of believers were considered by local bodies and in case of their approval were sent to the Council for Affairs of the Russian Orthodox Church; after that a preliminary decision came to the Council of People's Commissars and then again to the Council for Affairs of Churches. Such a procedure was developed with the purpose to dose opening of new churches and temples. By October, 1944 about 200 temples resumed church services, a considerable part of which were in Ukraine (Lysenko, 1998). The Kiev Pechersk Lavra came back to the Russian Orthodoxy; "miraculous power", cult attributes and icons withdrawn in the 20-30s were returned from stores of museum rooms to temples. Monasteries were restored to life. Evangelical Christians and Baptists acquired the right for creation of their own centres.

According to Stalin's plan, church had to use its channels in order to adjust international contacts of the USSR (Alekseev, 1991). The Stan newspaper issued in Chicago wrote: "The broadening of religious freedom will lead to the strengthening of the Soviet Union positions in its relations with western countries" (Sergeeva, 1943). For Stalin it was important to create a show of wellbeing in a religious question, and at the same time to keep church under a strict control as the part of his system behind this screen. He charged the National Committee for State Security with this work. For the implementation of a controlling role the Council for Affairs of the Russian Orthodox Church was created at the government of the USSR. It was headed by the colonel of state security G. G. Karpov. 
Since 1940 he headed the department which carried out anti-church actions. In the conversation with Karpov on October 13, 1943 Molotov pointed out to him the need to select representatives of the Council from the structure of security officers in regions and republics (Shkarovskiy, 1995).

In the instruction of the Council for Affairs of the Russian Orthodox Church for its representatives in the field approved on February 5, 1944 many provisions of the resolution of the VTsIK of 1929 were reproduced almost literally: "The activity of religious communities and attendants of cult has to be limited to cult purposes strictly... Due to the fact that religious communities have no rights of a legal entity, any production, trade, educational, medical and other activities are forbidden for them. Religious communities are granted the rights: to collect donations, to make the religious processions round temples which are a necessary part of church service if they do not stop traffic and also to make a ring in chapels; a registered priest was allowed to make some religious practices and services of need within his parish in believers' houses" (Yakunin, 2003).

Also the fabrication of "group" church plots proceeded. So in 1940-1941 bodies of the People's Commissariat for Internal Affairs discovered "a counterrevolutionary monarchic church organization" of the archbishop Petr (Fedoskin) in Arkhangelsk; in 1942 in Moscow they composed the group "plot of spiritual daughters of the archimandrite Serafim", and in 1942 "the anti-Soviet church organization" in the city of Kotlas was found (Kurlyandskiy, 2011).

On the issue of opening churches there was a secret instruction to delay the opening churches and open them only as a last resort, only under extraordinary pressure. So, V.M. Molotov specified in one of November conversations with G. G. Karpov: "Do not give any permissions to opening churches yet... Further apply to the government with the questions concerning opening for the sanction and only after that lower instructions to oblast executive committees... It is necessary to open churches in some places, but it will be necessary to constrain the solution of this question" (Shkarovskiy, 1995). Believers' applications about opening of churches were not considered in due time, and the majority of them were rejected. So, in 1944 the petitions of the believing Christians of Orthodox confession about opening the houses of worship and churches in Kounradsky mine oif the city of Balkhash were not satisfied (Soveta, 1944). The believers' petitions of Leninogorsk, the settlement of Belousovka of Kirovsky district of the East Kazakhstan region were condemned to the same failure (Komiteta, 1944). As reasons for rejection of the petitions were specified: lack of premises or unfitness of them because of their decay; existence of an already operating church or a house of worship; a personal initiative of the people applying on behalf of applicants; lack of necessary number of signatures and their falsification, also the use of the former cult buildings for production and other purposes. For example, according to the data as of January 1, 1945 in only one North Kazakhstan oblast only one church out of 50 operated, and premises of invalid churches were used in economic and cultural purposes (Tserkvah, 1945).

The Soviet power accepted donations of believers and church, but attempts of distribution of religion were rather rigidly stopped: in May, 1943 on the request of the People's Commissariat for Internal Affairs of the USSR such form of "patriotic service" of church as "patronage" of dioceses directly over concrete military hospitals, supply them with food, other necessary things, holding concerts and visiting injured soldiers by representatives of parishes and clergy was forbidden.

In modern Russian historiography there is an opinion on I. Stalin's religiousness and on essential influence of Orthodoxy on the inner world of Stalin (Efimov, 2001). A number of modern researchers (Yu, Vasil'yeva, \& Moss et al., n. d.) explain the mitigation of antireligious policy of the Soviet power with political goals. I. Stalin sought to use church for influence on public opinion. Church and clergy were very useful in the directing of the Russian patriotic and religious feelings to the pro-Soviet and anti-German course (Vasil'yeva, 2003; Moss, 2001).

In our opinion, the changes of Soviet power's religious policy can also be explained with the strengthening of the anti-Soviet promotion which was carried out by Germans in the occupied areas of the USSR. The Ministry of National Education and Propaganda and the Political Department of the Ministry of Foreign Affairs were the main centers of preparation of propaganda materials in the Third Reich. On the eve of the war the Wehrmacht and the Ministry on occupied eastern areas (the East Ministry) headed by A. Rozenberg also joined propaganda work. In April, 1939 the propaganda department was created at the High Command of the Wehrmacht.

The main contents of propaganda work were criticism of the weakest links of the Soviet system: collective farms, the Bolshevist solution to agrarian, national and religious problems, repressions, common people's working conditions and standards of living as well as exposure of the false information distributed by the Soviet propaganda. A huge attention was paid to the contents of propaganda materials, the experts studying economy of the Soviet Union, history, culture and spiritual life of Soviet people were attracted to their preparation. For example, one of the campaign materials which is kept in the Political archive of the Ministry of Foreign Affairs of Germany 
contains the characteristics of the state of religions and the state of affairs of priests in the USSR. The document begins with quotes from the Constitution of the USSR of 1936, and also from Lenin and Stalin's works about religion, and further the data on closing of mosques, churches, monasteries and synagogues by Bolsheviks, on the scales of repressions against ministers of worship are provided. The document includes the following statistics on repressions against religious institutions and clergy: the Soviet government closed 8000 churches in the first years after the revolution, 3000 churches in 1925-1928, 1200 churches in 1929, 2000 churches in 1930, 1400 churches in 1931-1935, 1100 churches in 1936-1937. The document also contains the data on closing of churches in large cities of Russia: in Moscow there were 420 churches on the eve of revolution, in 1934 only 37 remained (Lage, 1941).

On December 5, 1941 the staff of the Political Department of the Ministry of Foreign Affairs drew up the documents entitled "The Guidelines on Propaganda in the Caucasus" and "The Guidelines on Propaganda among Turkic Peoples". The latter document consisted of four points:

1) The time of liberation from the centuries old oppression of Moscow has come. Moscow and the Bolshevism, which have taken your best lands, grounds and have interfered by all means with cultural and economic development, are collapsing. Help to free your Homeland!

2) The German army is bringing to the Turkic peoples free development of their own culture and language, their religion and schools.

3) Such forms of land use, property and trade will be introduced that correspond to desires of various peoples.

4) The German empire treats all Muslims friendly and kindly. Don't trust the Bolshevist propaganda claiming that Muslims are tortured and shot (Aufbaumeldungen, 1941).

In the occupied territory Nazis tried to bring priests and heads of the religious organizations to their party. Moreover, in the occupied territories only the activity of religious organizations loyal to the German administration was allowed. Thus everything was done to support disintegrating processes among Orthodox parishes, dioceses and establishments on the occupied lands. The power did not wish to deal with uniform Orthodox church and therefore met the emergence and formation of independent churches favorably in the occupied territory. The processions which had to show "goodwill" of the German administration to the population were arranged in the occupied cities. The German scientist B. Quinkert describes how Germans celebrated "the day of liberation of Belarus from the Soviet yoke" on June 22, 1944 in Minsk. In the procession which took place in the center of Minsk the group of people had to bear images of destroyed churches as a symbol of the antireligious policy of the Soviet power (Quinkert, 2009). However, the German fascism was not less hostile to Christianity and especially the Russian Orthodox Church than the Soviet communism; nevertheless, their collision, which led to the occupation by the German army of a considerable part of the territory of the USSR with approximately one third of the population of the country, created special conditions which played a crucial role in the destiny of the Russian Orthodox Church (Alekseev \& Stavru, 1980).

\section{Conclusion}

According to the above mentioned facts it can be argued that during World War II the Soviet power's religious policy characterized by some mitigation with a string of concessions, but a radical change or as some researchers state "a liberal turn" did not occur. A number of actions had a declarative, nominal and propaganda character. The Soviet authorities did not plan to change "a church course". The turn had a declarative, nominal and propaganda character. The relations between Soviet power and the Russian Orthodox Church during World War II and bureaucracy in the opening of churches can serve as evidence of it. Superficially the mutual understanding seemed to remain between the power and church, while in reality the power sought to limit its influence in society in every possible way. Also it is impossible to exclude the influence of the German factor on the mitigation in the religious policy of the Soviet power. However, the aspiration to use alternative ways and forms of relationship between the state and church to strengthen Stalin's personal authority was probably the main reason for the mitigation of the Soviet power's antireligious policy.

\section{References}

Alekseev, I. V., \& Stavru, F. (1980). Russkaya Pravoslavnaya Tserkov' na okkupirovannoy nemtsami territorii. Russkoe vozrozhdenie, 11, 91-96.

Alekseev, V. A. (1991). Illyuzii i dogmy. M.: Politizdat.

Aufbaumeldungen des Reichsministers für die besetzten Gebiete. (1941). In Politisches Archiv des Auswärtigen Amts (Berlin). R 105168, Bd. 4. 
Die religiose Lage in den bezetsten Ostgebieten. (1941). I: Politisches Archiv des Auswärtigen Amts (Berlin). R 105169 , Bd. 5.

Efimov, V.T. (2001). Pravoslavie v dushenastroe Stalina. Veril li Stalin v Boga. M.: Parad.

Husband, W. B. (2000). "Godless Communists": Atheism and Society in Soviet Russia, 1917-1932. DeKalb: Northern Illinois University Press.

Khalid, A. (2007). Islam after Communism: Religion and Politics in Central Asia. Berkeley: University of California Press.

Kommunisticheskaya partiya Kazakhstana $v$ rezolyutsiyah $i$ resheniyah s'ezdov, konferentsiy i plenumov (1921-1927). Sbornik dokumentov i materialov. T. 1. (1987). Almaty: Kazakhstan.

Kurlyandskiy, I. A. (2011). Stalin, vlast', religiya (religioznyj i tserkovnyj faktory vo vnutrenney politike sovetskogo gosudarstva v 1922-1953 gg.). M.: Kuchkovo pole.

Lysenko, A. E. (1998). Religiya i tserkov' na Ukraine nakanune i v gody vtoroy mirovoy voyny. Voprosy istorii, 4 , 52.

Moss, V. (2001). Pravoslavnaya tserkov' na pereput'e. (1917-1999). SPb.: Aleteyya. Retrieved from http://www.portal-credo.ru/site/index.php?act=lib\&id=98

Quinkert, B. (2009). Propaganda und Terror in Weissrussland 1941-1944: Die deutsche "geistige" Kriegführung gegen Zivilbevölkerung und Partisanen. Paderborn: Schöningh Verlag.

Reshenie ispolnitel'nogo Komiteta Vostochno-Kazakhstanskogo Oblastnogo Soveta deputatov trudyaschihsya g. Ust'-Kamenogorsk ot 15 marta 1944 goda "O hodataystve veruyuschih Korolevoy L. P., Graborovoy N.P. i drugih, v chisle 63-h chelovek iz g. Leninogrska ob otkrytii russkoy pravoslavnoy tserkvi”. In: Tsentral'nyj gosudarstvennyj arhiv Respubliki Kazakhstan. Fond 1709. Opis'1. Delo 3. List 10.

Reshenie ispolnitel'nogo Komiteta Vostochno-Kazakhstanskogo Oblastnogo Soveta deputatov trudyaschihsya g. Ust'-Kamenogorsk, N 276 ot "28" aprelya 1944 g. o hodataystve gr-na Egorova A.A., upolnomochennogo o gruppy veruyuschih, ob otkrytii russkoy pravoslavnoy tserkvi v rabochem poselke Belousovka, Kirovskogo rayona, Vostochno-Kazakhstanskoy oblasti. In: Tsentral'nyj gosudarstvennyj arhiv Respubliki Kazakhstan. Fond 1709. Opis'1. Delo 3. List 14.

Ro'i, Y. (2000). Islam in the Soviet Union: From World War II to Perestroika. New York: Columbia University Press.

Schwartz, S. S. (2009). Islam and Communism in the 20th Century: An Historical Survey. Washington: Center for Islamic Pluralism.

Sergeeva, N. (1943, November 15). O religii i tserkvi v SSSR (po stranitsam inostrannoy pechati). Voyna $i$ rabochiy klass, 18-20.

Shkarovskiy, M. V. (1995). Russkaya Pravoslavnaya tserkov'v 1943-1957 godah. Voprosy istorii, 8, 37-38.

Shkarovskiy, M. V. (2010). Russkaya Pravoslavnaya Tserkov'v 20 veke. Moskva: Veshe.

Steindorff, L. (2001). Secularization in Soviet Russia - A Comparative Analysis. The Place of Russia in Eurasia (p. 336). Budapest: Magyar Ruszistikai Intézet.

Timofeeva, L. V. (2007). Istoriya Russkoy Pravoslavnoy tserkvi na territorii Semirech'ya (vtoraya polovina 19 veka- 20 vek). Avtoref. diss... kand. ist. nauk. Almaty, KazNPU.

Upolnomochennomu Soveta po delam russkoy pravoslavnoy tserkvi pri SNK KazSSR - tov. Gryaznyh. Informatsiya o sostoyanii raboty po Karagandinskoy oblasti ot 10 iyulya 1944 g. In: Tsentral'nyj gosudarstvennyj arhiv Respubliki Kazakhstan. Fond 1709. Opis'1. Delo 1. List 1, 15-16.

Vasil'yeva, O. Y. (2003). “Tserkovnyj stalinizm”: legendy i fakty. Al'manah "Al'fa i Omega”, 4(38). Retrieved from http://www.pravmir.ru/cerkovnyj-stalinizm-legendy-i-fakty/\#ixzz3MdEapVIL

Yakunin, V. N. (2003). Ukreplenie polozheniya Russkoy pravoslavnoy tserkvi i struktura ee upravleniya v 19411945 gody. Otechestvennaya istoriya, 4, 83-92.

\section{Copyrights}

Copyright for this article is retained by the author(s), with first publication rights granted to the journal.

This is an open-access article distributed under the terms and conditions of the Creative Commons Attribution license (http://creativecommons.org/licenses/by/3.0/). 